\title{
REDAKSIONEEL
}

\section{TWINTIG JAAR}

In die Skriflig gaan met hierdie nommer sy twintigste jaar binne. Onwillekeurig dink 'n mens terug aan wyle dr. K S van Wyk de Vries wat die vader van die gedagte van die GTV met sy eie mondstuk was. Destyds het hy, prof. J L Helberg en skrywer hiervan 'n besoek aan Potchefstroom gebring om oor die oprigting van so 'n blad te raadpleeg. Daar was nie baie hoop dat dit volgehou kan word nie, maar Van Wyk de Vries het geglo dat die Gereformserde Teologie op 'n breër vlak as net op Universitêre terrein sy stcm moet laat hoor.

Die Here het die onderneming wonderlik geseën. Dit sou egter sonder die voortdurende steun van kerke, referente en intekenaars nie moontlik gewees het nie. Daarbenewens word in stilte wonderlike werk uit liefde vir die blad gedoen. Hier moet 'n mens allermeeste dink aan mev. Ina Kruger van Hammanskraal wat so noukeurig die administrasie behartig. Potch. Herald behartig van die begin af die drukwerk. Die Here was vir ons goed met finansiële gawes mense om te skryf en te lees en te administreer wat In die Skriflig sy tweede dekade laat binnerol. Mag die tydskrif ten spyte van sy klein agterban en nederige opset, tog steeds gereformeerde teologie uitdra tot eer van God en uitbreiding van sy heerskappy deur sy Woord.

\section{KERKVERENIGING}

Kerkvereniging het in die 20ste eeu met sy aksent op die sosiale, internasionale en ekumeniese 'n besondere aktualiteit verkry. In Transvaal het in Desember 1885 die historiese kerkvereniging plaasgevind waardeur die Nederduitsch Hervormde Kerk en die Nederduits Gereformeerde Kerke van die land verenig het om die Nederduits Hervormde of Gereformeerde Kerk (tot 1962 veelal as Verenigde Kerk bekend) tot stand te bring. Pas hierna het geblyk dat die konsulentsgemeente van Pretoria, Witpoortjie, nie saamgegaan het nie en geleidelik het Hervormde mense nie gehou van wat hulle ervaar het nie en weer Hervormde gemeentes herstig, sodat die "kerkvereniging" eintlik net 'n kort droom was.

In hierdie uitgawe word gekyk na die Gereformeerdes en die beweging vir kerkvereniging in die vorige eeu. Skynbaar was daar in Transvaal 'n sterk gevoel, ook onder Gereformeerdes, om minstens een volkskerk in Transvaal te hê. Die kerkvereniging speel dan ook binne tipiese kollegiumdenke van struktuurbou af. Die nugter en realistiese advies van die Sinode van 1882 te Pretoria het die Gereformeerdes die euforie en smart wat kerkvereniging meegebring het, gespaar. Die vraag is of die vertolking van die "eenheid van die kerk" as institusionele oorkoepelende organisatoriese kerkeenheid die toets van die Skriftuurlike kerkbegrip en verskeidenheid in die menslike werklikheid kan verdiskonteer. Die kerk is 
immers per definisie eenheid in Christus, wat deur niks opgehef kan word nie. Die "kerk as eenheid" is nie sinoniem met "eenheid van die kerk" nie, veral nie sedert die Aufklährung die idee van die kerk as onpersoonlike en oorkoepelende Societas na vore gedwing het nie.

\section{BURGERLIKE ONGEHOORSAAMHEID}

Die etikus van Kampen, prof. J Douma, het onlangs besoek afgelê en oor burgerlike ongehoorsaamheid gepraat. Terug in Nederland het hy ook uitvoerig en krities in Nederlands Dagblad geskryf. Die voordrag bedoel waarskynlik nie Bybels-etiese teologiese begronding nie, maar bied 'n welmenende kritiese siening van 'n Gereformeerde teoloog uit Europese hoek. Dit is goed om kennis te neem van hoe ander op die Suid-Afrikaanse situasie reageer. Daardeur kan eie kennis en ervaring alleen verdiep.

\section{SKRIFGESAG}

In hierdie uitgawe volg die slotaflewering van dr. B J de Klerk se indringende eksegetiese studie oor gesag in die NT. Dit is seker die mees aktuele vraagstuk in moderne teologie. Ons opereer so graag met die cliché dat ons die Woord van God onvoorwaardelik in kerkregering en ons persoonlike lewe eerbiedig. Die vraag is egter of ons dit werklik bedoel en nastreef. 'n Mens hoef net na die vorm van kerklike besluite te kyk en met jou oor op die internasionale kerklike pers te lê, om op te merk dat kerkgesag en teologiese gesag veel hoër as die Bybel aangeslaan word. Die opvatting dat die Bybel maar net die oorkonde van die godsdienstige ervaring van Bybelskrywers was, open die weg om eie subjektiewe uitgangspunte met "Bybelse" gesag te beklee. Dit verg kritiese ondersoek om te bepaal in hoeverre eie subjektiewe oortuigings en uitgangspunte vandag as die gesag van die Skrif aangedien word - ook by onsself. Oor gesag laat De Klerk se studie geen twyfel nie.

Die diskussie tussen prof. Loader en Van Wyk raak-raak aan verskillende opvattings oor hierdie saak. 